3 Duckworth G. Diagnosis and management of methicillin resistant Staphylococcus aureus infection. BMf 1993;307: 1049-52.

4 Keane CT, Cafferkey MT. Methicillin-resistant Staphylococcus aureus: a guide to epidemiology and control. Rev Med Microbiol 1991;2:50-6.

5 Vichyanond P, Olson LC. Staphylococcal CNS infections treated with vancomycin and rifampin. Arch Neurol treated with 6 .

6 Gordon JJ, Harter DH, Phair JP. Meningitis due to Staphylococcus aureus. Am $\mathcal{F}$ Med 1985; 78:965-70.

7 Ferree B, Stambough JL, Greiner AL. Spinal epidural abscess. A case report and literature review. Orthopaedic Rev abscess. A case

8 Hoefnagels WA, van Poucke GE, Casselman JW, van Kleef JG, Vannerem LT. An abscess as an unexpected complication following epidural anaesthesia. Ned Tijdschr Geneeskd 1994;138:580-2
9 Baker A, Ojemann RG, Swartz M, Richardson EP. Spinal epidural abscess. N Engl f Med 1975;293:463-8.

10 Dei-Anang K, Hase U, Schurmann K. Epidural spinal abscesses. Neurosurg Rev 1990;13:285-8.

11 Leys D, Lesoin F, Vidaud C, et al. Decreased morbidity from acute bacterial spinal epidural abscess using computed tomography and non-surgical management in selected patients. Ann Neurol 1985;17:350-5.

12 Mampalam TJ, Rosegay H, Andrew BT, et al. Non operative treatment of spinal epidural infections. $\mathcal{\Im}$ Neurosurg $1989 ; 71$ : 208-10.

13 Working party of British Society of Antimicrobial Chemotherapy and Hospital Infection Society. Guidelines on the therapy and Hospital Infection Society. Guidelines on the control of methicillin resistant Staphylococt

14 Sakamoto T, Kikuchi K, Mineura K, Kowada M, Nakagomi $O$. MRSA meningitis in postoperative patients. Report of 4 cases. $\mathfrak{f p}_{p} \mathcal{\Im}$ Antibiot 1990;43:1137-42.

\title{
Hypertension and renal failure
}

\author{
D J A Goldsmith, G Hamilton
}

A 74-year-old man with a history of intermittent claudication, cigarette-smoking, hypertension, and a successful recent right nephro-ureterectomy for a right ureter transitional cell carcinoma, presented with abnormal renal function and hypertension (plasma creatinine $228 \mu \mathrm{mol} / 1$ and blood pressure $200 / 100 \mathrm{mmHg}$ on quinapril $20 \mathrm{mg}$ ). Fundoscopy showed grade II hypertensive changes. There was no abdominal bruit. There was no blood and only a trace of protein on urine reagent strip testing; phase-contrast urinary sediment microscopy was normal; 24-h protein excretion was $0.2 \mathrm{~g}$ (normal $<0.2 \mathrm{~g} / 24 \mathrm{~h}$ ), and creatinine clearance was $36 \mathrm{ml} / \mathrm{min}$. Prior to the right nephrectomy, renal function had been abnormal (plasma creatinine $184 \mu \mathrm{mol} / \mathrm{l}$ ).

Ultrasound of his abdomen showed a nonobstructed $9.3 \mathrm{~cm}$ left kidney with increased echogenicity and reduced cortical thickness. Isotope renography while on an angiotensin-converting

Trafford Department of Renal Medicine, Royal Sussex County Hospital, Brighton, East Sussex BN2 5BE, UK

D J A Goldsmith

University

Department of

Surgery, Royal Free

Hospital, Pond St,

London NW3 2QG, UK

G Hamilton

Accepted 19 November 1997 enzyme (ACE) inhibitor showed no activity on the right (nephrectomy) and definite but sluggish excretion by the left kidney. Frusemide $40 \mathrm{mg}$ /day was added, which reduced blood pressure a little $(175 / 90 \mathrm{mmHg})$, but caused plasma creatinine to rise from 241 to $312 \mu \mathrm{mol} / 1$.

Quinapril was continued at $20 \mathrm{mg}$ daily and lacidipine $4 \mathrm{mg}$ was added. The patient could not tolerate any strength of any other calcium channel blocker, nor a beta- or an alpha-blocker. Blood pressure rose further. Quinapril was increased to $40 \mathrm{mg} /$ day, and plasma creatinine rose again to $386 \mu \mathrm{mol} / 1$. Echocardiography showed significant left ventricular hypertrophy and diastolic dysfunction.

\section{Questions}

1 Is it likely that this patient has glomerulonephritis?

2 What is the most probable reason for the raised blood pressure and worsening renal function?

3 What options are available for effecting an improvement? 
Answers

QUESTION

It is unlikely that this patient has glomerulonephritis, as there was negligible proteinuria, no microscopic haematuria, and normal urinary sediment.

\section{QUESTION 2}

The most probable reason for the raised blood pressure and worsening renal function is renal arterial stenosis in a solitary kidney.

QUESTION 3

Angioplasty, arterial stenting and reconstructive surgery can all be useful in this condition.

\section{Clinical course}

Magnetic resonance angiography of his left renal artery strongly suggested an osteal renal artery lesion, confirmed at formal angiography, by which time the patient was experiencing breathlessness on exertion, orthopnoea and angina, and plasma creatinine was $420 \mu \mathrm{mol} / \mathrm{l}$, creatinine clearance $20 \mathrm{ml} / \mathrm{min}$, and blood pressure typically $200-210 / 90 \mathrm{mmHg}$. The degree of stenosis was so severe that the osteal meatus was a pinhole, and was occluded by the guide wire, so angioplasty with arterial stenting was abandoned. Quinapril was stopped and blood pressure controlled using lacidipine 6 $\mathrm{mg}$, verapamil $240 \mathrm{mg}$, celiprolol $400 \mathrm{mg}$, and frusemide $80 \mathrm{mg}$. He was anticoagulated with heparin to forestall renal artery occlusion. $\mathrm{He}$ then underwent a left splenorenal bypass to relieve 95-99\% left renal artery stenosis. Postoperatively there was a brisk diuresis, a marked improvement in renal function, and a marked fall in blood pressure. Some six months after the bypass surgery the patient is very well and has typical blood pressure values of 140/84 $\mathrm{mmHg}$ on lacidipine $4 \mathrm{mg}$ daily. Plasma creatinine is $164 \mu \mathrm{mol} / 1$ with creatinine clearance of $46 \mathrm{ml} / \mathrm{min}$. Exercise tolerance is limited only now by claudication; orthopnoea, breathlessness and angina have all resolved.

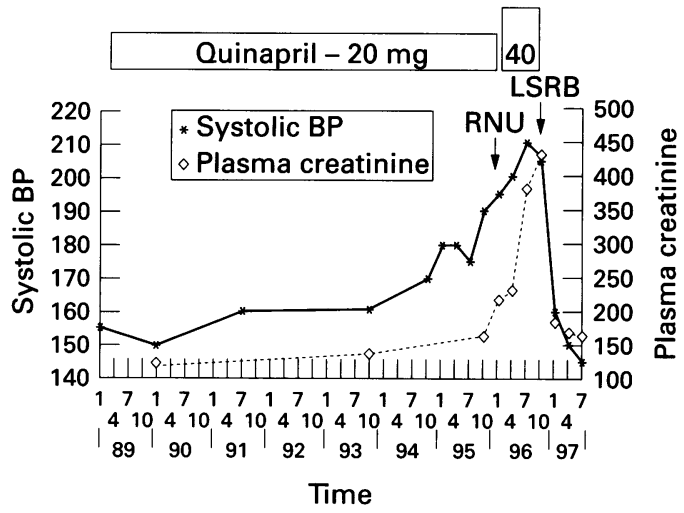

Figure 1 Time-plot of renal function and average blood pressure (BP). Nephro-ureterectomy (RNU) and renal arterial bypass (LSRB) are marked with arrows

\section{Pre Bypass}

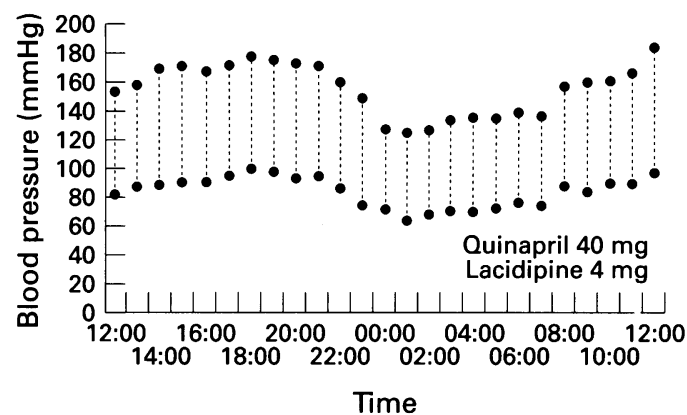

Post Bypass

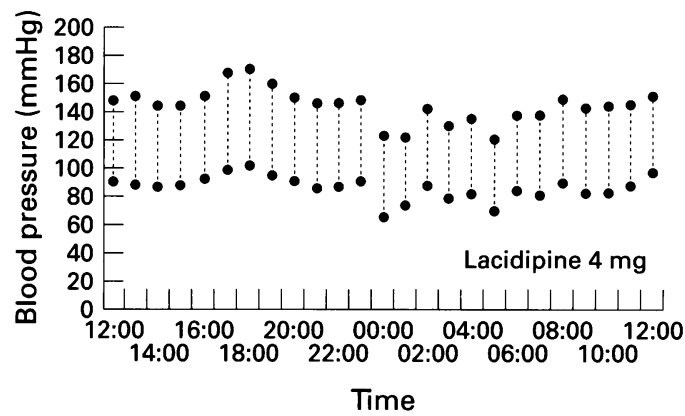

Figure 2 24-h Ambulatory blood pressure traces for subject six months before renal bypass (when on quinapril $40 \mathrm{mg}$, lacidipine $4 \mathrm{mg}$ ), and three months after renal bypass (when on lacidipine $4 \mathrm{mg}$ alone)

The course of blood pressure and renal function is given in figure 1 . Figure 2 shows the results of ambulatory blood pressure monitoring before and after the renal bypass.

\section{Discussion}

Renovascular disease is an important cause of acute and chronic renal failure. It is in part remediable by angioplasty, stenting or surgery. ${ }^{12}$ In younger patients the pathology is fibromuscular hyperplasia, and can affect several arterial segments of both kidneys. In older patients the pathology is atherosclerosis, often contiguous with aortic disease and maximal peri-osteally. ${ }^{3}$

Early diagnosis and intervention are important; clinical clues are refractory hypertension, 'flash pulmonary oedema', worsening renal function with the start or increase in ACE inhibitor (often reversible with ACE inhibitor withdrawal), renal bruit (neither a sensitive nor a specific sign) and contextual (age, smoking, atherosclerosis elsewhere ${ }^{5}$ ). Unilateral disease is often accompanied by renal size and functional asymmetry, the latter accentuated by test doses of an ACE inhibitor. No noninvasive method of diagnosis is as accurate as renal angiography; although spiral computed tomography has a sensitivity and selectivity of $95 \%$.

\section{Final diagnosis}

Renal artery stenosis in a single kidney following nephrectomy.

Keywords: renal artery stenosis; hypertension 
1 Zucchelli P, Zuccala A. Ischemic renal failure. Contrib Nephrol 1996;119:59-66.

2 Donohue $\mathrm{P}$, de Takats D, Bishop N, et al. A four-year audit of interventional treatment for atheromatous renal artery of interventional treatment for atheroma

3 Mailloux LU, Napolitano B, Bellucci AG, Vernace M Wilkes BM, Massey RT. Renal vascular disease causing Wilkes BM, Massey RT. Renal vascular disease causing end-stage renal failure: incidence, clinical correlates and 1994;24:622-9.
4 Missouris CG, Buckenham T, Vallance PJT, MacGregor GA. Renal artery stenosis masquerading as congestive cardiac failure. Lancet 1993;341:1521-2.

5 Olin JW, Melia M, Young JR, Graor RA, Risius B Prevalence of atherosclerotic renal artery stenosis in patient with atherosclerosis elsewhere. Am f Med 1990;88:146N $151 \mathrm{~N}$.

\title{
Pleural effusion and a pelvic mass
}

\author{
D Agranoff, D May, C Jameson, G K Knowles
}

A 56-year-old woman presented with a nine-month history of lassitude, weight loss, an unproductive cough and increasing breathlessness. There was no complaint of chest pain or haemoptysis and she had never smoked. Examination revealed signs of a massive right pleural effusion, confirmed on chest X-ray (figure 1), and a large pelvic mass. There was no clinically detectable ascites, hepatosplenomegaly or lymphadenopathy. Full blood count, erythrocyte sedimentation rate, urea and electrolytes, liver function tests and blood calcium were all normal.

Approximately four litres of yellow fluid were removed by pleural drainage and multiple pleural biopsies were obtained. At laparotomy, a large mass was discovered in the right ovary (figure 2). The uterus contained multiple fibromyomata but no peritoneal nodules were present and there was no ascites.

Kingston Hospital, Galsworthy Road, Kingston upon Thames, Surrey KT2 7QB, UK Department of Medicine

D Agranoff

G K Knowles

Department of

Obstetrics and

Gynaecology

D May

Department of

Histopathology

C Jameson

Correspondence to $\mathrm{Dr}$

Knowles

Accepted 19 November 1997

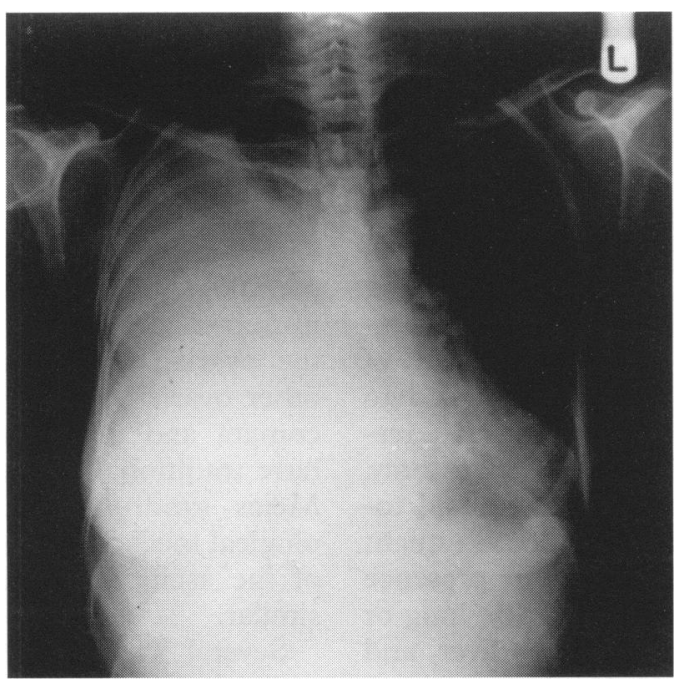

Figure 1 Chest X-ray showing right pleural effusion

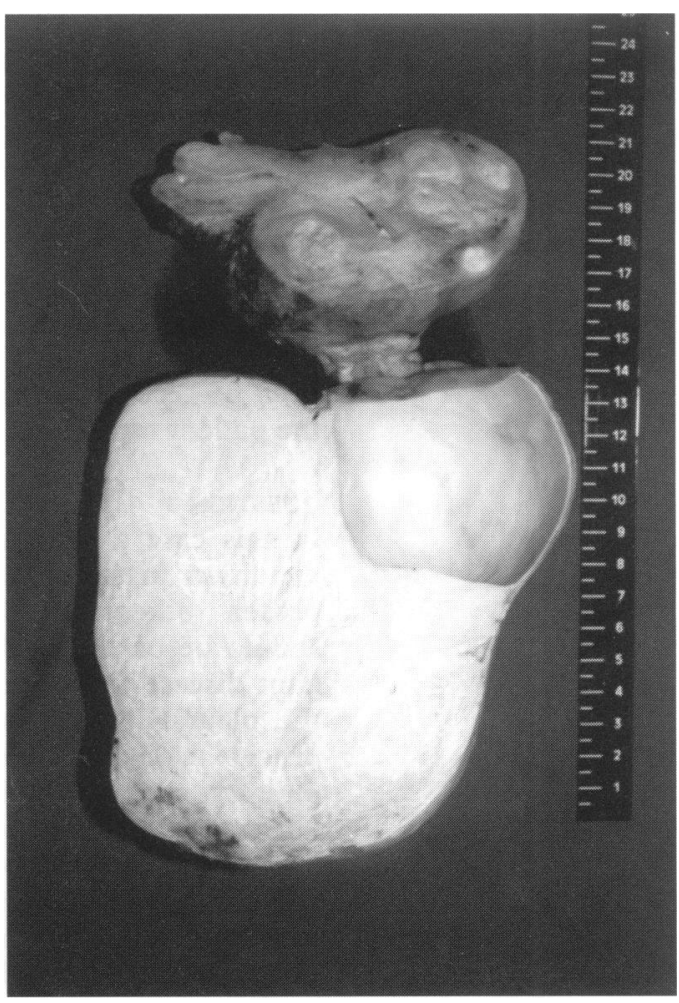

Figure 2 Right ovarian tumour attached to uterus containing multiple fibromyomata

\section{Questions}

1 What is the most probable diagnosis?

2 What additional diagnoses should be considered?

3 What is the correct management in this situation? 